of its effect on mineralization and growth. With the exception of the rachitogenic diet, growth rates were high and comparable on these diets, with no difference observed between male and female rats.

Renal deposits of calcium were histologically demonstrable within 3 weeks of weaning female rats on to the standard pellets. The calcification commenced at the cortico-medullary junction, where it remained most dense throughout life, but later spread into the medulla. The cortex remained unaffected although there was some enlargement of the deposits with increasing age. Electron microscopy revealed the deposits to be usually lamellated and to be both intracellular and intra-tubular in location. A fow deposits had the typical appearance of hydroxyapatite.

\begin{tabular}{|c|c|c|c|c|c|c|}
\hline Sex & $\begin{array}{c}\text { Age } \\
\text { (weeks) }\end{array}$ & Diet & Treatment & Calcium & $\begin{array}{l}\text { Phos- } \\
\text { phorus }\end{array}$ & Histology \\
\hline $\mathbf{M}$ & 26 & $P$ & - & 0.38 & $12 \cdot 20$ & Negative \\
\hline F & $6-8$ & $P$ & - & $\begin{array}{r}1.00 \\
1.12\end{array}$ & 13.60 & Positive \\
\hline F & 26 & $P$ & - & $\begin{array}{r}12.10 \\
+14.00\end{array}$ & $\begin{array}{r}16.20 \\
+6.0\end{array}$ & Positive \\
\hline F & $11-18$ & $C$ & 一 & $\begin{array}{r}0.37 \\
+0.01\end{array}$ & 12.60 & Negative \\
\hline M & $5-11$ & $P$ & Castrated & $\begin{array}{r}0.39 \\
+0.05\end{array}$ & $\begin{array}{r}13 \cdot 10 \\
+1.1\end{array}$ & Negative \\
\hline M. & $9-12$ & $P$ & DHT & $\begin{array}{r}3.41 \\
+\quad .80\end{array}$ & $\begin{array}{l}14.20 \\
+0.08\end{array}$ & Positive \\
\hline F & 5-11 & $P$ & Ovariectomized & 0.39 & 13.60 & Negative \\
\hline$\frac{\mathrm{M}}{\mathrm{F}}$ and & 10 & $P$ & $\begin{array}{l}\text { Gonadectomized } \\
\text { + oestroform }\end{array}$ & $\begin{array}{r}3.96 \\
\pm 2.33\end{array}$ & $\begin{array}{r}13 \cdot 80 \\
\pm 0.32\end{array}$ & Positive \\
\hline
\end{tabular}

$P$, Commercial pellet diet; $C$, control 'Farex' diet; DHT, dihydrotachysterol, $1 \mathrm{mg}$ per $100 \mathrm{~g}$ body-weight by intraperitoneal injection; analytical data as means with standard deviations in $\mathrm{mg} / \mathrm{g}$ dry weight of kidney, minimum of seven animals in each group.

Kidney mineralization following administration of hypercalcaemic agents such as parathyroid hormone, dihydrotachysterol and vitamin $\mathrm{D}$ is well known. With nephrocalcinosis induced by these agents there is a diffuse distribution of mineral throughout the kidney, the cortex being most affected ${ }^{3}$; death from renal failure is a common event with these treatments. A feature of the femalespecific renal calcification described in this report is that the affected animals were apparently healthy, with normal weight gain, ability to withstand multiple pregnancies, normal serum calcium and phosphorus levels and no impairment of renal function as judged by blood urea measurements.

Experimental work has shown that the sex specificity of this nutritional nephrocalcinosis is related to oestrogen level. A group of female rats was ovariectomized and weaned at $30 \mathrm{~g}$ weight on to the standard pellet diet. Periodic examination of kidneys from these animals showed the absence of renal deposits over the 8 weeks of observation. In a similar experiment both male and female rats were gonadectomized and received $100 \mu \mathrm{g}$ of oestradiol benzoate ('Oestroform', British Drug Houses, Ltd.) twice weekly by intramuscular injection while fed on standard pellets. Within 3 weeks all animals had developed the typical renal deposits. The results of some of these treatments are summarized in Table 1, which also gives analyses for total calcium and phosphorus in the decapsulated kidneys. These quantitative data give an index of the magnitude of the calcification and illustrate its progression with age in the female rats.

Both oestrogens and a dietary factor are implicated in the aetiology of the condition described. The nutritional factor remains undetermined, but it would seem that it is not related to absolute levels of calcium and phosphorus, vitamin $\mathrm{D}$ or magnesium in the diet.

F. B. Cousins

C. P. M. Geary

Biochemical Research Unit,

University of Otago Dental School,

Dunedin, New Zealand.

${ }^{1}$ Ludwig, T. G., Malthus, R. S., and Healy, W. B., Nature, 194, 456 (1962).

2 Steenbock, H., and Black, A., J. Biol. Chem., 64, 263 (1925).

Scarpelli, D. G., Lab. Invest., 14, 123 (1965).

\section{Isolation of Fluorescent Components from Ox-bone Human Dentine and Gelatine}

EARLIER investigations ${ }^{1-4}$ on the fluorescent material in calcified tissues have indicated that it is associated with the collagenous organic matrix of these tissues. Observations on soluble tissue matrix preparations showed they had excitation maxima at $330 \mathrm{~m} \mu$ with corresponding emission maxima about $400 \mathrm{m \mu}$.

Using a 'Sephadex' ion-exchange column (C.25 CM at $p H 4 \cdot 2$ ) we have now successfully separated the fluorescent material from alkaline hydrolysates of ox bone, human dentine and gelatine preparations with $80-90$ per cent recovery. The isolated material possessed a characteristic ultra-violet absorption spectrum with maxima at $264 \mathrm{~m} \mu$ and $325 \mathrm{~m} \mu$. The fluorescent excitation and emission maxima of the isolated material were $330 \mathrm{~m} \mu$ and $400 \mathrm{~m} \mu$, respectively, and were identical to those obtained from both solid and solution preparations of the corresponding intact matrices. Fluorescence was destroyed by bromination and permanganate oxidation. The isolated material fractionated on a 'Sephadex $G-10$ ' gel filtration column into two components, with identical fluorescence characteristics.

Consideration has been given to the concepts that the fluorescence associated with calcified tissue proteins may arise either from a separate substance bound to the matrix or, alternatively, be the property of some intrinsic structural feature of the collagen molecule itself. Our results indicate that the fluorescent material survives alkaline hydrolysis of the total matrix, and can apparently exist as a separate entity, with the same excitation and emission characteristies in the isolated state as when associated with the matrix. It presumably possesses oxidation and bromination sensitive centres. From the gel-filtration results a tentative estimate of a molecular weight of less than 700 for the material may be made, the results also indicating that the fluorescence is associated with two fractions of differing molecular weight.

We thank the Medical Research Council for financial support.

\section{W. G. Armstrong \\ Helena Joan Horsley}

Royal Dental Hospital,

School of Dental Surgery,

University of London,

Leicester Square,

London, W.C.2.

${ }^{1}$ Hartles, R. L., and Leaver, A. G., Biochem, J, 54, 632 (1953),

'Laurila, U-R., Mancewicz, S. A., and Forsiati, A. F., J. Dent. Res., 39, 714 (1960).

Armstrong, W. G., Arch. Oral Biol., 8, 79 (1963).

4 Mancewicz, S. A., and Hoerman, K. C., Arch. Oral Biol., 9, 535 (1964).

\section{Freezing of Bound Water and Protein Aggregation in Frozen Cod Muscle stored near its Melting Point}

THE muscle proteins of frozen fish slowly aggregate at a rate depending on the temperature. Since the reaction causes the flesh to become tough to eat, and eventually unacceptable to the consumer, a considerable research effort has been directed towards means of slowing it down-the usual method being to keep the temperature as low as possible.

In cod (Gadus morhua L.) air-blast frozen at $-30^{\circ} \mathrm{C}$ the change proceeds most rapidly between $-1^{\circ}$ and $-2^{\circ} \mathrm{C}$ (ref. 1), and it was therefore surprising to learn recently that fish landed in Portugal after storage on a catching vessel at temperatures just below their freezing point ("superchilled") had suffered little damage to their proteins ${ }^{2}$. The trials were repeated under laboratory conditions in this country ${ }^{3}$ and, after thawing, the samples 